ACTA MYCOLOGICA

Vol. 48 (1): 51-59

2013

DOI: $10.5586 / \mathrm{am} .2013 .007$

\title{
Parasites of zooplankton and periphyton assemblages in the littoral zone of lakes in Drawa National Park, Poland
}

\author{
MARIA WOLSKA and KINGA MAZURKIEWICZ-ZAPAŁOWICZ
}

West Pomeranian University of Technology in Szczecin, Department of Hydrobiology Ichthyology and Biotechnology of Reproduction, 4 K. Królewicza St., PL-71-550 Szczecin

Wolska M., Mazurkiewicz-Zapałowicz K.: Parasites of zooplankton and periphyton assemblages in the littoral zone of lakes in Drawa National Park, Poland. Acta Mycol. 48 (1): 51-59, 2013.

Studies on parasitism in zooplankton and periphyton assemblages were carried out on samples of water collected from Lakes Płociczno and Płociowe in the Drawa National Park in 2008-2011. Occurrence of the fungal mycobiotal and protozoan parasites of invertebrates was recorded in both lakes. Parasitism of Chydorus sp. (Cladocera) by Saprolegnia sp. occurred on $0.8 \%$ of individuals of the host population, of Brachionus calyciflorus (Rotifera) by Microsporidium sp. on $1.2 \%$ of the host population, and of Nematoda members by Pythium sp. on $5 \%$ of the host population. Parasites were recorded only in springtime.

Key words: mycobiota, microsporidia, microparasities, plankton, periphyton

\section{INTRODUCTION}

Plankton and periphyton are a complex mixture of organisms that make a significant contribution to the littoral zone of lakes. The composition of these assemblages is affected by abiotic and biotic factors and is under continuous and dynamic change. The periphyton consists of a network of complex configurations of organisms with complex interspecies relationships. In the aquatic environment, the least known are still the relationships between the invertebrata (kingdom: Animalia) and fungi (kingdom: Fungi/Mycota), as well as between invertebrata and protozoan fungal analogues (kingdom: Protozoa) and chromistan fungal analogues (kingdom: Chromista). Parasitism is particularly important in these relationships. It often determines the density of individual species in water. Organisms that comprise the plankton and periphyton are potential hosts of various ecto- and endoparasites. There are susceptible in varying degrees to infection, the success of which depends also on genetic factors (Stirnadel, Ebert 1997). Parasites of plankton and periphyton organisms additionally modify the physiological and behavioral processes of their hosts, which is followed by changes in density, survival, fecundity and lifespan of the host 
(Mirakle 1977; Ruttner-Kolisko 1977) and growth rate of the population (Thomas et al. 2011). There has been continued interest in zooparasites present in the aquatic habitat for the last 150 years, since the first zooparasitic protozoan fungal analogues species, Amoebidium parasiticum Cienk. was recorded on the copepod cyclops (Cyclopidae) (Whisler 1962; Whisler, Fuller 1968). Although it is known that plankton and periphyton assemblages include fungi, protozoan and chromistan fungal analogues saprotrophs, parasites and predators (Kiziewicz and Czeczuga 2003), our knowledge of their occurrence, as well as their contribution and significance in sustaining the equilibrium of aquatic ecosystems, is inadequate.

Studies using various approaches aimed at recognition of parasites of plankton and periphyton organisms are therefore necessary. They will provide new information on the functioning and relationships in assemblages of parasites and their hosts. Such knowledge is of particular value in the case of natural bodies of water, particularly those located in environmentally sensitive and protected areas. The proper functioning of successive links of the microbial loop (including plankton and periphyton parasites) in these ecosystems is of particular significance.

The aim of this study was to determine the occurrence of parasites in zooplankton and periphyton assemblages in the littoral zone of two lakes in Drawa National Park in Poland.

\section{MATERIALS AND METHODS}

Studies on parasitism in the zooplankton and periphyton assemblages were carried out on samples of water collected from two lakes in the Drawa National Park. Samples were collected from Lake Płociowe, which is mesotrophic and has no throughflow, in 2008-2009, and from Lake Płociczno, which is eutrophic and has throughflow, in 2011. Samples were collected three times each year, in April/May (spring circulation), August (summer stagnation) and November/December (autumn circulation), from five sites in the littoral zone of each lake.

Zooplankton samples were taken with a 5-L "Toń" sampler from water 0-1 m deep. On each occasion, $50 \mathrm{~L}$ of water was collected in 10 hauls. The water was filtered through a plankton net with a $44 \mu \mathrm{m}$ diameter mesh. The total sample of zooplankton from the two lakes resulted from filtration of $2250 \mathrm{~L}$ of water. Additional zooplankton assemblages were collected using a net for a $2 \mathrm{~min}$ period through the water among plants. The samples of zooplankton were then preserved in $4 \%$ formaldehyde solution. Rotifera and Crustacea (Invertebrata) were counted and identified to species in a $1 \mathrm{ml}$ chamber using a microscope (Nikon Eclipse E 200) at 60-240x magnification. Taxonomy was determined by morphology according to Flössner (1972), Kiefer and Fryer (1978), and Radwan et al. (2004).

Periphyton samples were collected from submerged shoots of the hydrophytes, Phragmites australis (Cav.) Trin. ex Steud. and Carex acutiformis L. Two pieces, approximately $10 \mathrm{~cm}$ long, were cut from each shoot and preserved in 5\% formaldehyde solution. A total of 180 pieces from 90 shoots was analysed from each lake. Two methods were used to determine the occurrence of parasites on the periphyton organisms. The first was microscopic observation of a suspension collected from 
approximately $3600 \mathrm{~cm}^{2}$ of plant surface. The second was similar to that used in the study of zooplankton.

Zooplankton and periphyton organisms were assessed for their state of health and possible interactions with parasites, mainly with those from protozoan and chromistan fungal analogues. The parasites were determined based on morphology according to Skirgiełło (1954) and Khulbe (2001) using a Nikon Eclipse E 200 biological microscope and 60-800x magnification. Nomenclature of fungi, protozoan and chromistan fungal analogues was adopted according to Index Fungorum (www. indexfungorum.org) and their classification according to Kirk et al. (2008).

\section{RESULTS AND DISCUSSION}

The zooplankton in the littoral zone of Lake Płociowe was dominated by Cladocera (92\% of the total population) and of Lake Płociczno by Rotifera (50\% of the total). The mean abundance of the zooplankton organisms was 213 individuals $\mathrm{L}^{-1}$ in Lake Płociowe in 2008-2009, and 140 individuals $\mathrm{L}^{-1}$ in Lake Płociczno in 2011. The mean abundance of particular taxonomic groups of zooplankton in each lake in each season in 2008-2011 is shown in Figure 1.

Host responses to parasites in zooplankton assemblages were assessed for 34, 25 and 7 taxa of animals: Rotifera (phylum), Cladocera (phylum Arthropoda) and Copepoda (phylum Arthropoda), respectively, in Lake Płociowe, and for 57, 30 and 18 taxa of Rotifera, Cladocera and Copepoda in Lake Płociczno.

Protozoan and chromistan fungal analogues parasites of the zooplankton organisms were found to occur only in spring, in 2009 in Lake Płociowe and in 2011 in Lake Płociczno. The possible explanation of such short-duration, seasonal occurrence of parasites is a highly dynamic succession, which results in elimination of protozoan and chromistan fungal analogues by bacteria. Bacteria are the most

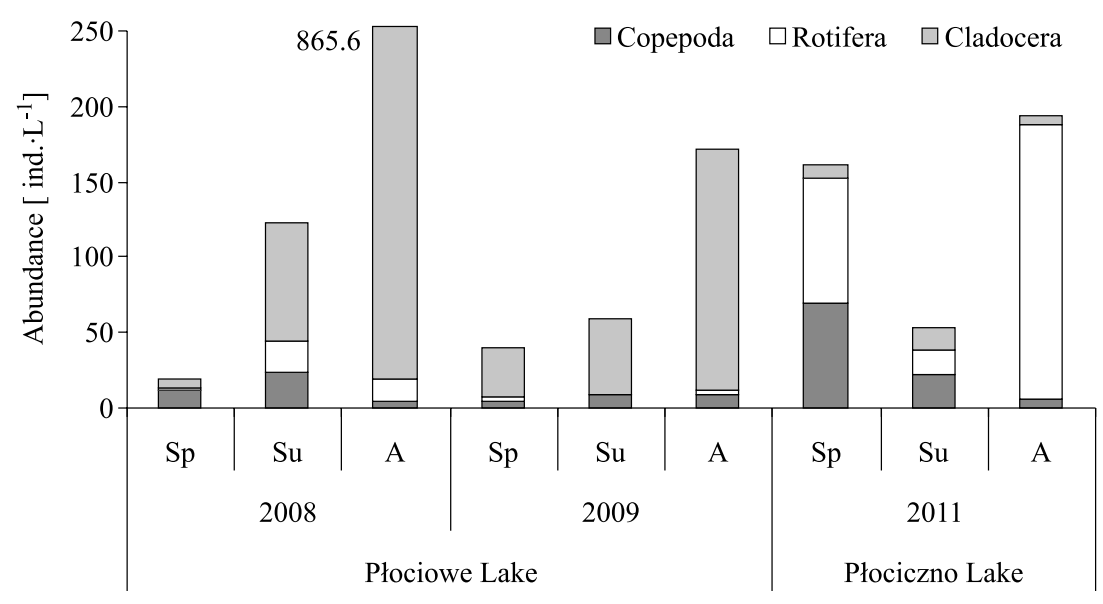

Fig. 1. The mean abundance of particular taxa of zooplankton in Lakes Płociowe and Płociczno in 2008-2011; Sp - spring, Su - summer, A - autumn. 


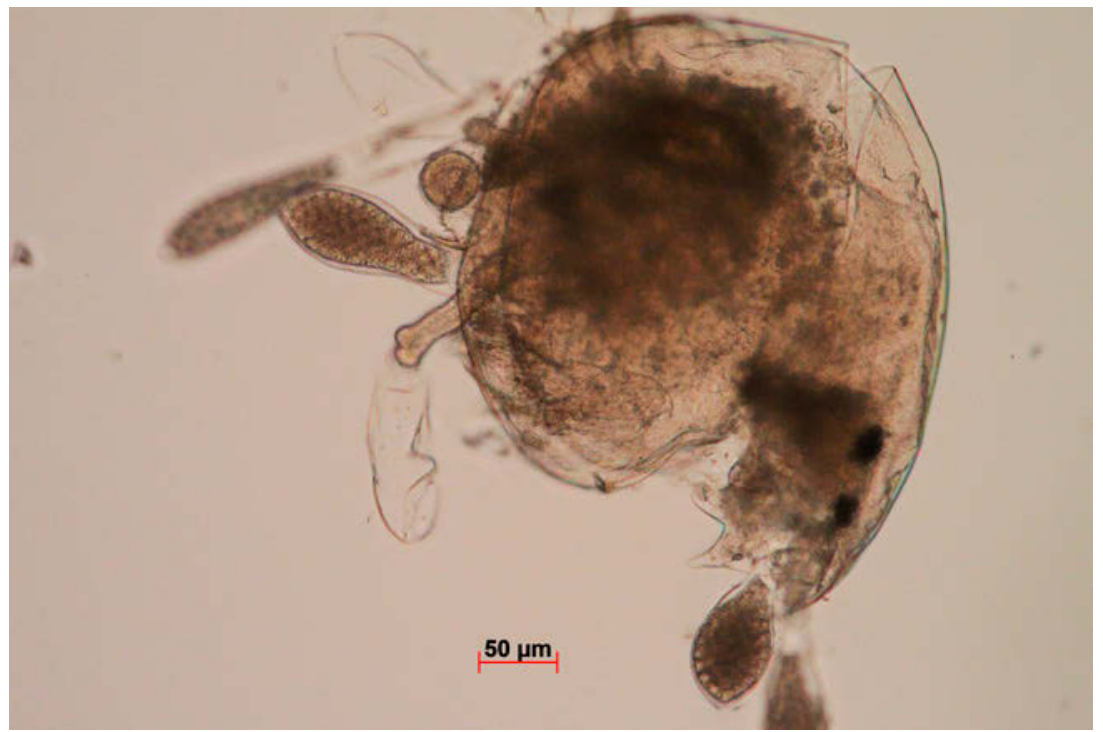

Fig. 2. Chydorus sphaericus (Cladocera) infected with Saprolegnia sp. - zoosporangia with zoospores.

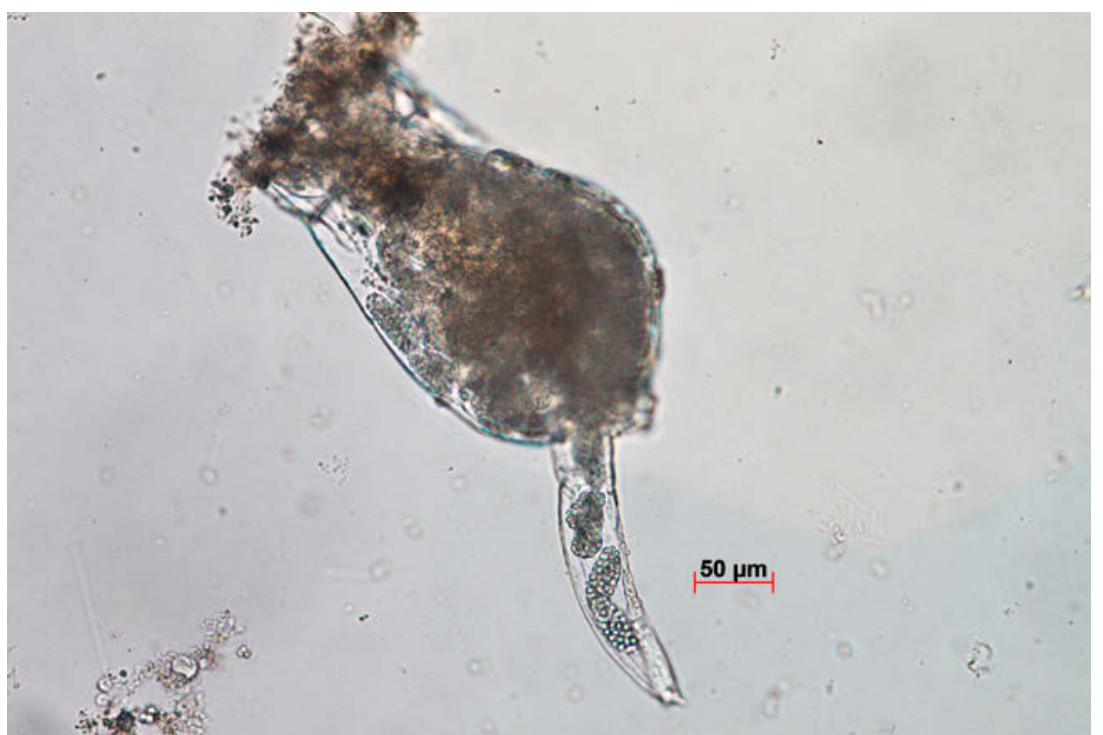

Fig 3. Brachionus calyciflorus (Rotifera) infected with Microsporidium sp.

commonly recorded destructive agents, being continuously present in large numbers and having high biochemical activity (Ebert 1995; Decaestecker et al. 2005).

Only one case of parasitism of Chydorus sphaericus (Cladocera, Chydoridae) (O.F. Müller) by Saprolegnia sp. (chromistan fungal analogues, kingdom Chromista) was recorded in Lake Płociowe (Fig. 2). Infection was observed on $0.8 \%$ of 
the Chydorus population, which accounted for $6.7 \%$ of all Cladocera. There were no other fungi and fungal analogues parasites of zooplankton in Lake Płociowe. An example of parasitism of Brachionus calyciflorus (Rotifera) by protozoan Microsporidium sp. was recorded in Lake Płociczno (Fig. 3). The parasite was recorded on $1.2 \%$ of the B. calyciflorus population.

These single examples of parasitism, although not very impressive, may be considered representative and credible because they were recorded in very large samples of zooplankton.

Comparision of the results with similar studies. As already mentioned, the first zoopathogenic species observed in aquatic environment was protozoan fungal analogue Amoebidium parasiticum Cienk. parasitising on Cyclopoidae (Copepoda) (Whisler 1962). Parasites Coelomomyces psorophorae Couch ex Couch (kingdom: fungi, phylum: Chytridiomycota) were identified by Guilvard et al. (1977) and Goettel (1987) on mosquito larvae. The larvae of these insects were also infected by two species of protozoan fungal analogues, i.e. Hyalinocysta chapmani E.I. Hazard \& Oldacre (Andreadis 2002) and Amblyospora sp. (Nasci et al. 1987). In Poland, the occurrence of fungi and fungal analogues on planktonic arthropods (Cladocera, Copepoda and Rotifera) was studied by Czeczuga et al. (2000) and Kiziewicz (2004). In these studies a total of 29 Cladocera species were identified, among which dominant were chromistans Lagenidium gigantem Couch and Ancylistes cladocerarum Fritsch (fungi, phyllum: Zygomycota). They were observed throughout the year in all phases of the development of these crustaceans. Species L. giganteum was also most frequently identified on Rotifera, together with Olpidium granulatum Karling (kingdom: fungi, phyllum: Chytridiomycota). Mycoses of rotifers have also been caused by other species, i.e. Chytriomyces aureus Karling (kingdom: fungi; phyllum: Chytridiomycota) and chromistan Myzocytium microsporum (Karling) Sparrow and M. zoophthorum Sparrow. Most published studies concern the occurrence of parasitic microorganisms on dead (Czeczuga et al. 2000; Godlewska et al. 2003) or alternatively living zoohydrobionts, though in laboratory conditions (Lass, Ebert 2006; Wolinska et al. 2009). To date, however, not many in situ studies related to parasitic infections of live zooplankton and zooperiphyton. Most often they concerned Cladocera parasites, including Daphnia spp., forming at times large populations in small water reservoirs (Brambilla 1983; Stirnadel, Ebert 1997; Wolinska et al. 2004). There are also studies on Rotifera parasites occurring in rivers (Gorbunov, Kosova 2001).

Results presented here are similar to and comparable with those reported by Goren and Ben-Ami (2013), who studied the ecological relationships between cladocerans and their endoparasites in 204 freshwater bodies. They recorded a total of 21 taxa of endoparasites on 14 taxa of Cladocera. Only two parasites belonged to kingdom Fungi, i.e. Metschnikowia bicuspidate (Metschn.) (phyllum: Ascomycota) and brood pouch parasite. Four of them were bacteria species, eleven constituted protozoan organisms from Microsporidium group, while four were unclassifified parasites. The most common endoparasites were bacteria - Spirobacillus cienkowskii Metchnikoff and protozoan fungal analogeus - Glugoides intestinalis Chatton. Comparatively few species of parasitic eukaryotes was reported by Gorbunov and Kosova (2001), who found only one representative of the chromistan fungal analogues (Pythium sp.) and two species of fungi, (Catenaria anguillulae Sorokin and Olpidium 
gregarium Nowakowski) in more than 20 species of Rotifera from water bodies in delta of the Volga river. Pythium sp. was, however, the most commonly encountered and present in water throughout the year.

Other authors have reported, however, a greater contribution of fungi and fungal analogues in the parasitism of zooplankton. Czeczuga et al. (2000) isolated 29 species of parasites from dead specimens of Cladocera. The most common species, recorded throughout the year, in all growth stages of these small crustaceans were the chromistan fungal analogues Lagenidium giganteum Couch and fungal Ancylistes sp. (phyllum: Zygomycota). The former, together with Olpidium granulatum (kingdom: Fungi; phyllum: Chytridiomycota), was also the most common on rotifers. Mycoses of Rotifera were caused also by other fungi, namely Chytriomyces aureus Karling and chromistan fungal analogues: Myzocytiopsis microspora (Karling) M.W. Dick [= Myzocytium microsporum] and Myzocytiopsis zoophthora (Sparrow) M.W. Dick [= Myzocytium zoophythorum $]$.

Wolinska et al. (2009) recorded four species of protosoan fungal analogues ( $M i$ crosporidium group), one species of fungi and nine chromistan fungal analogues members among 14 parasites infecting Daphnia. Czeczuga et al. (2000) found, in studies of parasitism of Copepoda, that the occurrence of a particular fungal and protozoan and chromistan fungal species was limited to a single season. In this study also the tendency for seasonal occurrence of mycobiotal zooparasites was indicated. Their abundance increased in spring, resulting from the local and seasonal presence and abundance of hosts. Therefore, where the host occurs only locally and seasonally, parasitism will be local and short-term, with low-moderate significance.

Reasons for dynamic occurrence of parasites of zooplankton and periphyton. The sporadic occurrence of parasites may result from the generally low abundance of zooplankton. This was observed in both lakes (Fig. 1). In Lake Płociczno, the low incidence of infestation of Brachionus calyciflorus (Rotifera) by Microsporidium sp. was associated with the low abundance of the potential host in the zooplankton (although the abundance of zooplankton in general was high). This observation agrees with Duffy et al. (2005), who pointed out that low abundance of the host population limits the spread of its parasite. Infestation of B. calyciflorus by Microsporidium asperospora may, however, be more common (even on 30-40\% of the host population), as observed in water bodies of the Volga delta (Gorbunov, Kosova 2001).

The frequency of occurrence of parasites on zooplankton organisms may be affected additionally by the size and shape of the host organism. Brambilla (1983), and Stirnadel and Ebert (1997) found a positive correlation between size of the host (Daphnia species) and percentage of population infested. Populations of D. magna Straus ( $>2.4 \mathrm{~mm}$ long), D. pulex Leydig ( $>1.7 \mathrm{~mm}$ long) and D. longispina Müller ( $<1.3 \mathrm{~mm}$ long) were infested, on average, at $85 \%, 53.6 \%$ and $38.6 \%$, respectively. The tendency to colonize and infest larger organisms results not only from exposure of a greater surface area of the host to the parasite but is also associated with the host's physiology. Larger species of Daphnia filter more water while feeding, and thereby absorb more spores of mycobiota and invasive stages of parasites present in the water (Ebert 1995). This suggestion seems to be indirectly confirmed by our own studies, as the largest species of Daphnia, i.e. D. magna was not found in littoral plankton. This species is most susceptible to infection by microorganisms and they 
increase epidemic spread of pathogens in the population. This could, however, have resulted from the early infestation of $D$. magna and its consecutive elimination. Infected and diseased individuals are more distinctive and can be the preferred target of planktivorous fish hunting by sight (Yan and Larsson 1988). Reduction of the host by planktivorous fish may lead to decreased parasites' diversity (Duffy et al. 2005; Wolinska et al. 2009).

Success of infection of zooplankton by both ecto- and endoparasites results also from the susceptibility of the host or pathogenicity of the parasite. Variation in susceptibility among hosts may be affected by the structure and composition of the cuticle. Variation in pathogenicity of the parasite may depend also on its biochemical activity. Endomycosis of Chydorus sphaericus caused by Saprolegnia sp. (Fig. 2) may result from proteolitic or cytotoxic activity of the latter. Both kinds of activity have been observed in S. monoica Pringsh., and S. parasitica Coker (Mazurkiewicz-Zapałowicz et al. 2008). They may cause degeneration of the host's hemocoel (tissue spaces) resulting in death of the host. In parasitism of Brachionus individuals by Microsporidium group, eventual death of the host is associated with the accumulation of spores (Fig. 3).

Greater incidence of parasitism seems to result also from the horizontal distribution and migration of zooplankton in the littoral zone, which increases the chance of meeting the spores of parasites. This suggestion is supported by studies of Ebert (1995), who found, in laboratory experiments, a positive correlation between accumulation of parasite spores and the level of parasitism of zooplankton.

In the periphyton assemblages, consisting of Protozoa (protozoan phylum Ciliophora: Coleps sp., Peritricha and ameboid protists: Testacea), Rotifera, Ostracoda, Cyclopoida (nauplii), Cladocera (Chydoridae - Alona guttata Sars., A. guadrangula (O.F.M.), Chydorus sp.), Oligochaeta (Chaetogaster von Baer, Stylaria Lamarck), Nematoda and Diptera (larval stages of Chironomidae), and Nematoda. Only Nematoda, in Lake Płociczno, were parasitized by Pythium sp. This parasite appeared only in spring 2011 and reached a prevalence of 5\%, which is not high considering that Nematoda accounted for $11 \%$ of organisms in the periphyton. While most of the species of Pythium are pathogenic to plants recent studies on Daphnia (Cladocera) in Europe (Wolinska et al. 2009), and on Asplanchna Gosse (Rotifera) in the USA (Thomas et al. 2011) and Russia (Gorbunov, Kosova 2001) have showen that the genus also includes species pathogenic to water invertebrates.

\section{CONCLUSIONS}

This study confirms the presence of diverse, unique and specific interactions resulting from the presence of parasites within freshwater zooplankton and periphyton assemblages. The diversity of these interactions may result from a high level of adaptability of the parasites to the local habitat. This means that recognition of dynamic relationships in the microbial loop system is difficult, which emphasizes the need for further studies.

Acknowledgements. The studies were supported by Ministry of Science and Higher Education, grant no. NN 304 385639. The authors of the paper thank the Management of Drawa National Park (Poland) for their help in collecting the research material. The authors are grateful to the anonymous reviewers for valuable comments and suggestions on the manuscript. 


\section{REFERENCES}

Andreadis T.G. 2002. Epizootiology of Hyalinocysta chapmani (Microsporidia: Thelohaniidae) infections in field population of Culiseta melanura (Diptera:Culicidae) and Orthocyclops modestus (Copepoda: Cyclopidae): a tree-year investigations. J. Invert. Pathol. 81 (2): 114-121. http://dx.doi.org/10.1016\%2FS0022-2011\%2802\%2900154-4

Brambilla D.J. 1983. Microsporidiosis in a Daphnia pulex population. Hydrobiologia 99: 175-188. http://dx.doi.org/10.1007\%2FBF00008769

Czeczuga B., Godlewska A., Kozłowska M. 2000. Zoosporic fungi growing on the carapaces of dead zooplankton organisms. Limnologica 30: 37-43. http://dx.doi.org/10.1016\%2FS0075-9511\%2800\%2980040-7

Decaestecker E., Declerck S., De Meester L., Ebert D. 2005. Ecological implications of parasites in natural Daphnia populations. Oecologia 144 (3): 382-390. http://dx.doi.org/10.1007\%2Fs00442-005-0083-7

Duffy M., Hall S.R., Tessier A. J., Huebner M. 2005. Selective predators and their parasitized prey: Are epidemics in zooplankton under top-down control? Limnol. Oceanogr. 50: 412-420. http://dx.doi.org/10.4319\%2Flo.2005.50.2.0412

Ebert D. 1995. The ecological interactions between a microsporidian parasite and its host Daphnia magna. J. Anim. Ecol. 64: 361-369. http://dx.doi.org/10.2307\%2F5897

Flössner D. 1972. Die Tierwelt Deutschlands. 60 Tiel. Krebstiere, Crustacea. Kiemen-Blattfüßer, Branchiopoda, Fischläuse, Branchiura. VEB Gustaw Fischer Verlag, Jena (in German).

Goettel M.S. 1987. Field incidence of mosquito pathogens and parasites in central Alberta. J. Am. Mosq. Control. Assoc. Jun. 3 (2): 231-238.

Godlewska A., Czeczuga B., Kiziewicz B., Kurzątkowska A. 2003. Występowanie grzybów wodnych na martwych osobnikach grzbietopławka Notonecta glauca L. Streszczenia plakatów i referatów: 46. XIX Zjazd Hydrobiologów Polskich, Warszawa (in Polish).

Gorbunov A.K., Kosova A.A. 2001. Parasites in rotifers from the Volga delta. Hydrobiologia 446/447: 51-55. http://dx.doi.org/10.1023\%2FA\%3A1017569004998

Goren L., Ben-Ami F. 2013. Ecological correlates between cladocerans and their endoparasites from permanent and rain pools: patterns in community composition and diversity. Hydrobiologia 701:13-23. http://dx.doi.org/10.1007\%2Fs10750-012-1243-5

Guilvard E., Rioux J.A., Manier J.F., Pech-Perisres J. 1977. Coelomomyces psorophorae Couch, 1945 (Blastocladiales-Coelomomycetaceae), a parasite of Aedes detritus (Haliday, 1833) (Diptera-Culicidae) in the Camargue. Ann. Parasitol. Hum. Comp. Mar-Apr. 52 (2): 211-227.

Khulbe R. D. 2001. A manual of aquatic fungi (Chytridiomycetes \& Oomycetes). Daya Publishing House. Delhi.

Kirk M.P., Cannon P.F., Minter D.W., Stalpers J.A. 2008. Dictionary of the Fungi. $10^{\text {th }}$ ed., CABI Europe$\mathrm{UK}, 771$.

Kiefer F., Fryer G. 1978. Das Zooplankton der Binnengewässer. 2 Teil Freilebende Copepoda. E. Schweizerbart'sche Verlagsbuchhandlung, Stuttgart.

Kiziewicz B., 2004. Grzyby wodne występujące w Jeziorze Wigry Wigierskiego Parku Narodowego. (In:) R. Wiśniewski, J. Jankowski (eds). Ochrona i rekultywacja jezior: 81-90. V Konf. Nauk-Tech., Grudziądz (in Polish).

Kiziewicz B., Czeczuga B. 2003. Występowanie i morfologia niektórych drapieżnych grzybów pełzako-, wrotko- i nicieniobójczych w wodach powierzchniowych okolic Białegostoku. Wiad. Parazytol. 49 (3): 281-291 (in Polish).

Lass S., Ebert D. 2006. Apparent seasonality of parasite dynamics: analysis of cyclic prevalence patterns. Proc. R. Soc. B 273: 199-206.

Mazurkiewicz-Zapałowicz K., Silicki A., Grajewski J., Woźniak A. 2008. Studies on toxicity of selected Oomycetes. Acta Mycol. 43 (1): 13-19.

Mirakle M.R. 1977. Epidemiology in rotifers. Arch. Hydrobiol. Beih. Ergebn. Limnol. 8:138-141.

Nasci R.S., Hare S.G., Vecchione M. 1987. Habitatassociations of mosquito and copepod species. J. Am. Mosq. Control. Assoc. Dec. 3 (4): 593-600. (Erratum in J. Am. Mosq. Control. Assoc. 1990 Mar. 6 (1): 151).

Radwan S., Bielańska-Grajner I., Ejsmont-Karabin J. 2004. Rotifers (Rotifera), Freshwater fauna of Poland. 32. Oficyna Wydawnicza Tercja, Łódź (in Polish). 
Ruttner-Kolisko A. 1977. The effect of the microsporid Plistophora asperospora on Conochilus unicornis in Lunzer Untersee (LUS). Arch. Hydrobiol. Beih. Ergebn. Limnol. 8: 135-137.

Skirgiełło A. 1954. Grzyby niższe. Pragrzyby i glonowce. Przewodnik morfologiczno-systematyczny z kluczami do oznaczania. PWN, Warszawa (in Polish).

Stirnadel H.A., Ebert D. 1997. Prevalence, host specificity and impact on host fecundity of microparasites and epibionts in three sympatric Daphnia species. J. Anim. Ecol. 66: 212-222. http://dx.doi.org/10.2307\%2F6023

Thomas S.H., Housley J.M., Reynold A.N., Penczykowski R.M., Kenline K.H., Hardegree N., Schmidt S., Duffy M.A. 2011. The ecology and phylogeny of oomycete infections in Asplanchna rotifers. Freshwater Biol. 56: 384-394. http://dx.doi.org/10.1111\%2Fj.1365-2427.2010.02505.x

Whisler H. C. 1962. Culture and nutrition of Amoebidium parasiticum. Am. J. Bot. 49 (3): 97-191.

Whisler H.C., Fuller M.S. 1968. Preliminary observations on the holdfast of Amoebidium parasiticum. Mycologia 60 (5): 1068-1079. http://dx.doi.org/10.2307\%2F3757291

Wolinska J., Keller B., Bittner K., Lass S., Spaak P. 2004. Do parasites lower Daphnia hybrid fitness? Limnol. Oceanogr. 49 (2): 1401-1407. http://dx.doi.org/10.4319\%2Flo.2004.49.4_part_2.1401

Wolinska J., Giessler S., Koerner H., 2009. Molecular identification and hidden diversity of novel Daphnia parasites from European lakes. Appl. Environ. Microbiol. 75 (22): 7051-7059. http://dx.doi.org/10.1128\%2FAEM.01306-09

Yan N.D., Larsson J.I.R. 1988. Prevalence and inferred effects of microsporidia of Holopedium gibberum (Crustacea: Cladocera) in a Canadian Shield Lake. J. Plankton Res. 10: 875-886. http://dx.doi.org/10.1093\%2Fplankt\%2F10.5.875

Index Fungorum (www.indexfungorum.org)

\section{Pasożyty związane z organizmami planktonowymi i peryfitonowymi strefy litoralowej jezior Drawieńskiego Parku Narodowego}

\section{Streszczenie}

W latach 2008-2011 badano występowanie mikroorganizmów pasożytniczych na gatunkach tworzących zooplankton i peryfiton litoralowy w jeziorach Płociczno i Płociowe w Drawieńskim Parku Narodowym. Występowanie patogenów na organizmach tych zespołów stwierdzono jedynie wiosną. Udokumentowano porażenie Chydorus Leach (Cladocera) przez Saprolegnia sp., Brachionus calyciflorus Pall. (Rotifera) przez Microsporidium sp. oraz przedstawiciela Nematoda przez Pythium sp. Porażenie przez patogeny dotyczyło $0,8 \%$ populacji Chydorus sp., 1,2\% populacji Brachionus calyciflorus oraz 5\% populacji niezidentyfikowanych do gatunku nicieni (Nematoda). W pracy przeanalizowano uzyskane wyniki na tle innych, podobnych badań i przedyskutowano prawdopodobne przyczyny niewielkiego stopnia porażenia organizmów planktonowych i peryfitonowych przez pasożyty. Wskazano także na obserwowaną przez niektórych autorów zależność występowania pasożytów od dynamiki sezonowej występowania ich żywicieli. 